Penerapan Ekstrak Putri Malu (Mimosa pudica L..) sebagai Penghambat Melanosis.....(Nabila Tsarwatul Jannah et al.)

\title{
PENERAPAN EKSTRAK PUTRI MALU (Mimosa pudica L.) SEBAGAI PENGHAMBAT MELANOSIS PADA UDANG SELAMA PENYIMPANAN DINGIN
}

\section{Application of Mimosa pudica L. Extract on the Melanosis in Shrimp during Chilled Storage}

\author{
Nabila Tsarwatul Jannah*, Tri Winarni Agustini, dan Apri Dwi Anggo \\ Program Studi Teknologi Hasil Perikanan, Jurusan Perikanan, Fakultas Perikanan dan Ilmu Kelautan, \\ Universitas Diponegoro, Jl. Prof. Soedarto, SH, Tembalang, Semarang, Jawa Tengah \\ *Korespondensi Penulis: nabilatsarwatul@gmail.com
}

Diterima: 24 September 2017; Direvisi: 9 Maret 2018; Disetujui: 10 September 2018

\begin{abstract}
ABSTRAK
Salah satu masalah pada mutu udang selama penanganan adalah munculnya melanosis. Melanosis merupakan bercak hitam yang timbul akibat aktivitas enzim PPO (polifenoloksidase). Tanaman putri malu (Mimosa pudica L.) memiliki senyawa bioaktif yang dapat berfungsi sebagai antioksidan seperti flavonoid, fenol dan tanin. Penelitian ini bertujuan untuk mengetahui efektivitas dan konsentrasi terbaik ekstrak tanaman putri malu (Mimosa pudica L.) dalam proses enzimatis (melanosis) pada udang selama penyimpanan dingin. Konsentrasi yang digunakan adalah $0 \%$, $3 \%, 5 \%$ dan $7 \%$ dengan penyimpanan selama 10 hari dan pengujian dilakukan setiap 2 hari (hari ke 0, 2, 4, 6, 8 dan 10). Paramater pengujian yang diamati adalah uji melanosis secara visual, TBA, TVBN, sensori dan $\mathrm{pH}$. Rancangan percobaan yang digunakan adalah RAL. Hasil penelitian menunjukkan ekstrak tanaman putri malu memberikan pengaruh nyata dalam mempertahankan mutu udang dari terjadinya reaksi melanosis hingga hari ke-6. Konsentrasi terbaik adalah konsentrasi $7 \%$ yang dapat mempertahankan mutu udang hingga hari ke-6 karena konsentrasi $7 \%$ memiliki nilai hasil uji melanosis, TBA, TVBN, dan $\mathrm{pH}$ yang terendah serta nilai sensori tertinggi.
\end{abstract}

KATA KUNCI: putri malu, melanosis, udang, penyimpanan dingin, kesegaran

\begin{abstract}
One of shrimp handling problem is the appearance of melanosis. Melanosis is a blackspot appearance caused by PPO (Polyphenoloxidase) activity. Mimosa pudica $\underline{L}$. contains bioactive compound that has antioxidant properties such as flavonoid, phenols, and tannin. The aim of this research was to determine the effectiveness and the best concentration of mimosa plant extract on enzymatic process (melanosis) in shrimp during chilled storage. Concentration of $0 \%, 3 \%, 5 \%$ and $7 \%$ of mimosa plant extract was used with a 10 days storage and evaluated with parameters of melanosis assessment, TBA, TVBN, sensory and $\mathrm{pH}$ every 2 days (day 0, 2, 4, 6, 8 and 10). Completely Random Design was used as the experimental design. The results showed that the mimosa plant extract was able to mantain the quality of shrimp from melanosis until day 6 . The best concentration was $7 \%$ which successfully maintain the quality of shrimp until day 6 which had the lowest melanosis assessment, TBA, TVBN, and $\mathrm{pH}$ value and also had the highest sensory score.
\end{abstract}

KEYWORDS: Mimosa pudica, melanosis, shrimp, chilled storage, freshness

\section{PENDAHULUAN}

Udang merupakan salah satu komoditas ekspor utama di Indonesia. Dalam penanganannya, udang memiliki beberapa masalah. Salah satunya adalah muncul melanosis pada udang selama penanganan. Melanosis merupakan fenomena umum yang terjadi pada bahan bangan termasuk seafood. Melanosis disebabkan oleh enzim polifenoloksidase yang mengoksidasi fenol menjadi quinon. Polimerisasi kuinon menyebabkan munculnya pigmen hitam yang menimbulkan warna kehitaman pada udang (Montero, Martínez-Álvarez, \& Gómez-Guillén, 2004). Melanin merupakan pigmen yang dihasilkan oleh proses 
enzimatis. Pigmen ini tidak berbahaya bagi tubuh manusia, namun kehadiran pigmen ini dapat menyebabkan penolakan dari konsumen karena alasan kenampakan yang kurang menarik.

Salah satu upaya untuk mencegah munculnya melanosis adalah dengan memberikan perlakuan metabisulfit. Penggunaan metabisulfit sudah menyebar luas dan beberapa negara menerapkan peraturan mengenai pemakaiannya. Namun, belakangan ditemukan bahwa metabisulfit dapat menyebabkan gangguan kesehatan seperti reaksi alergi berupa asma. Selain itu, penggunaan yang berlebih dapat menyebabkan akumulasi residu yang selain dapat mengurangi nilai jual juga membahayakan kesehatan manusia (Erkan et al., 2007; Gomez-Guillen, MartinezAlvarez, Llamas, \& Montero, 2005).

Putri malu (Mimosa pudica L.) merupakan salah satu tanaman herbal yang memiliki banyak aktivitas farmakologi seperti agen, anti-diabetes, antitoxin, antihepatoxi, antioksidan dan penyembuh luka (Azmi, Singh \& Akhtar, 2011). Tanaman putri malu menunjukkan aktivitas antioksidan yang tinggi yang bisa dikaitkan dengan kandungan flavonoid dan fenol (Zhang, Yuan, Zhou, Zhou, \& Yang, 2011). Berdasarkan penelitian yang dilakukan oleh Patro, Bhattasamisra, Mohanty, dan Sahoo (2016), putri malu memiliki potensi antioksidan berdasarkan uji aktivitas antioksidan yang telah dilakukan yaitu $\mathrm{IC}_{50} 46,06 \mathrm{mg} /$ $\mathrm{mL}$ yang masuk kategori antioksidan kuat.

Putri malu juga telah diuji aktivitas antioksidannya terhadap enzim fenolase pada apel yang telah dikupas untuk melihat reaksi pencokelatan yang terjadi pada hitungan menit oleh Racadio (2016) di Filipina. Sementara Fadlian dan Abram (2016) melakukan studi tentang putri malu sebagai pengawet tomat. Penelitian menunjukkan bahwa ekstrak tanaman putri malu yang efektif dalam mengawetkan buah tomat adalah pada konsentrasi $6 \%$ dengan lama penyimpanan selama 11 hari.

Penelitian ini bertujuan untuk mengetahui pengaruh penerapan ekstrak tanaman putri malu sebagai zat antioksidan dalam menghambat melanosis pada udang selama penyimpanan dingin serta mengetahui konsentrasi terbaik berdasarkan parameter uji yang digunakan.

\section{BAHAN DAN METODE}

\section{Bahan dan Alat}

Bahan yang digunakan dalam penelitian ini adalah tanaman putri malu utuh (Mimosa pudica $L$.) yang terdiri atas daun, batang, akar, dan bunga. Tanaman putri malu diperoleh dari Watu Simbar, Gunung Pati,
Semarang. Tanaman putri malu yang digunakan memiliki ciri dalam kondisi segar, daun berwarna hijau, bunga utuh dan tidak rusak.

Udang putih (Litopenaeus vannamei) yang digunakan dalam keadaan utuh dengan memiliki kenampakan bening bercahaya, antar ruas kokoh, organ tubuh utuh serta memenuhi syarat mutu sensori berdasarkan SNI 01-2346-2006. Udang putih yang digunakan adalah udang putih yang berasal dari Mangkang, Semarang yang langsung diambil dari pengepul udang. Udang putih diangkut menggunakan coolbox yang berisi es curai untuk mempertahankan kesegarannya.

Alat yang digunakan dalam penelitian ini adalah rotary evaporator (Buchi), spektofotometer (UV Vis), alat destilasi, waterbath dan $\mathrm{pH}$ meter.

\section{Metode}

Dalam penelitian ini dilakukan penelitian pendahuluan untuk mengetahui senyawa bioaktif yang terkandung dalam tanaman putri malu serta besar rendemen yang dihasilkan dari ekstraksi. Penelitian utama bertujuan untuk mengetahui pengaruh ekstrak tanaman putri malu dalam mempertahankan kesegaran udang putih berdasarkan nilai uji melanosis, TBA, TVBN, sensori dan $\mathrm{pH}$. Rancangan dasar percobaan yang digunakan adalah rancangan acak lengkap (RAL) faktorial dengan menggunakan 2 faktor yaitu perlakuan sampel dengan konsentrasi $(0 \%, 3 \%$, $5 \%$ dan $7 \%$ ) yang berbeda dan lama penyimpanan dalam suhu dingin $0,2,4,6,8$ dan 10 hari.

\section{Metode ekstraksi}

Tanaman putri malu utuh yang terdiri atas daun, batang, akar, dan bunga dikeringkan dengan menggunakan paparan sinar matahari selama 5 hari kemudian dihaluskan menjadi serbuk. Serbuk tanaman putri malu diekstrak dengan metode maserasi selama 24 jam dengan pelarut etanol $96 \%$. Selama perendaman maserasi, ekstrak diaduk setiap 6 jam pertama dan didiamkan selama 18 jam berikutnya (Pal, Datta, Basnett, Shrestha, \& Mohanty, 2015). Filtrat disaring dengan menggunakan kertas saring Whatmann kemudian dikeringkan dengan rotary evaporator. Ekstrak disimpan pada suhu chilling untuk penggunaan lebih lanjut (Lakshmibai, Amirtham, \& Radhika, 2016).

\section{Pembuatan konsentrasi}

Konsentrasi yang digunakan dibuat dengan melarutkan $15 \mathrm{~g}$ ekstrak dalam $485 \mathrm{ml}$ aquadest untuk konsentrasi 3\%, $25 \mathrm{~g}$ ekstrak dalam $475 \mathrm{ml}$ aquadest untuk konsentrasi 5\%, dan $35 \mathrm{~g}$ ekstrak dalam 465 $\mathrm{ml}$ aquadest untuk konsentrasi $7 \%$. Pembuatan 
Penerapan Ekstrak Putri Malu (Mimosa pudica L..) sebagai Penghambat Melanosis.....(Nabila Tsarwatul Jannah et al.)

ekstrak tanaman putri malu mengacu pada penelitian Anggraini, Hamidah dan Moehammadi (2013), dengan menggunakan rumus pengenceran $\mathrm{N}_{1} \mathrm{~V}_{1}=\mathrm{N}_{2} \mathrm{~V}_{2}$. Penelitian menggunakan 4 konsentrasi dengan aquadest sebagai pelarut ekstrak.

\section{Analisa senyawa bioaktif}

Senyawa bioaktif dianalisis dengan menggunakan metode spektrofotometri dan gravimetri. Senyawa yang dideteksi adalah senyawa fenol dengan metode Harboune 1987. Senyawa flavonoid dianalisi dengan metode spektofotometri (Worotikan dalam Suryanto, 2007) sedangkan senyawa tannin dan senyawa saponin dilakukan dengan metode Gravimetri (Harboune, 1987).

\section{Penentuan rendemen ekstrak tanaman putri malu (Pendit, Zubaidah \& Sriherfyna, 2016)}

Penentuan rendemen ekstrak tanaman putri malu mengacu pada Pendit et al. (2016), metode yang digunakan untuk perhitungan rendemen ekstrak tanaman putri malu dilakukan dengan menimbang bahan awal dan bahan akhir, kemudian menghitung rendemen $(\% \mathrm{~b} / \mathrm{b})$ dengan persamaan :

$$
\text { Rendemen }=\frac{\text { berat bahan akhir }(\mathrm{g})}{\text { berat bahan awal }(\mathrm{g})} \times 100 \%
$$

\section{Preparasi sampel}

Udang putih sebanyak 100 ekor dengan ukuran konsumsi (10-18 g/ekor) dicuci dan dihilangkan kotorannya, kemudian direndam dalam 500 ml ekstrak tanaman putri malu dengan konsentrasi 3, 5 dan 7\% selama 30 menit. Dalam setiap tempat/wadah perendaman terdapat 25 ekor udang sesuai dengan konsentrasi dan waktu penyimpanan. Sampel dikemas dan disimpan pada suhu dingin $5 \pm 2 \stackrel{\circ}{ } \mathrm{C}$ dalam refrigerator. Waktu penyimpanan yang digunakan berbeda yaitu $0,2,4,6,8$, dan 10 hari.

\section{Pengujian melanosis (Otwell \& Marshall, 1986)}

Melanosis dapat diukur secara visual berdasarkan metode yang telah dikembangkan oleh Otwell dan Marshall (1986). Metode ini membutuhkan panelis untuk menilai seberapa jauh melanosis telah terjadi pada udang dengan membandingkan sampel dengan gambar udang yang telah diberi angka serta deskripsi. Penilaian melanosis dari jenis udang berbeda dilakukan melalui inspeksi visual oleh tiga puluh panelis semi-terlatih dan menggunakan sepuluh poin penilaian, yaitu 0: tidak tampak (absent), 2: sedikit tampak (slight) dan mudah untuk dilihat di beberapa bagian udang (noticeable on some shrimps), 4: sedikit tampak (slight) dan mudah untuk dilihat di hampir semua bagian udang (noticeable on most shrimps), 6: tampak moderate dan mudah untuk dilihat di hampir semua bagian (noticeable on most shrimps), 8: tampak heavy dan mudah untuk dilihat di hampir semua bagian udang (noticeable on most shrimps), 10 : sangat tampak heavy dan sangat tidak dapat diterima (totally unacceptable).

\section{Pengujian angka TBA (Tarladgis, Watts, \& Younathan, 1960)}

Penentuan angka TBA dilakukan dengan menggunakan metode Tarladgis et al. (1960) di mana 2-Thiobarbituric acid bereaksi dengan malonaldehid membentuk warna merah, intensitas warna merah yang terbentuk dapat diukur pada aspek trifotometer. Malonaldehid merupakan hasil oksidasi lipid yang absorbansinya diukur pada panjang gelombang 528 $\mathrm{nm}$ dengan larutan blanko sebagai titik nol. Angka TBA yang dihitung, dinyatakan dalam mg malonaldehid per kg sampel.

\section{Pengujian angka TVBN (BSN, 2009)}

Pengujian TVBN dilakukan berdasarkan prosedur yang tertera pada SNI 2354.8-2009 (BSN, 2009). Pada prinsipnya analisis TVB didasarkan pada peningkatan senyawa basa mudah menguap sebagai hasil degradasi protein dengan asam borat yang selanjutnya dititrasi menggunakan $\mathrm{HCl}$

\section{Pegukuran pH (BSN, 2004)}

Prosedur pengukuran $\mathrm{pH}$ dengan menggunakan $\mathrm{pH}$ meter yang dikalibrasi terlebih dahulu dengan larutan buffer $\mathrm{pH} 4$ setiap akan melakukan pengukuran.

\section{Pengujian sensori (BSN, 2006)}

Uji sensori udang segar dilakukan berdasarkan SNI No. 01-2346-2006 (BSN, 2006). Pengujian sensori dilakukan oleh 30 orang panelis agak terlatih menggunakan scoresheet sensori udang segar dengan spesifikasi kenampakan, bau dan tekstur. Skor yang digunakan mempunyai range 1-9, skor 1 untuk nilai terburuk dan skor 9 untuk nilai terbaik.

\section{HASIL DAN PEMBAHASAN}

\section{Rendemen Ekstrak Tanaman Putri Malu}

Rendemen ekstrak tanaman putri malu yang dihasilkan menggunakan pelarut etanol $96 \%$ sebesar $3,11 \%$. Jumlah rendemen ekstrak yang dihasilkan dipengaruhi oleh beberapa faktor, yaitu ukuran simplisia, jenis pelarut, tingkat kepolaran pelarut dan lama maserasi. Menurut Pendit et al. (2016), tingkat 
kepolaran pelarut yang digunakan mempengaruhi tingkat kelarutan suatu senyawa bahan yang diekstraksi ke dalam pelarut. Jenis dan tingkat kepolaran pelarut menentukan jenis dan jumlah senyawa yang dapat diekstrak dari bahan. Rendemen ekstrak akan cenderung meningkat dengan semakin meningkatnya rasio bahan dan pelarut yang digunakan.

\section{Fitokimia Kuantitatif}

Hasil uji fitokimia ekstrak tanaman putri malu, menunjukkan bahwa tanaman putri malu positif mengandung flavonoid, tanin dan asam galat. Besarnya kandungan bioaktif senyawa flavonoid sebesar $0,08 \%$; senyawa tanin sebesar $0,57 \%$; dan senyawa asam galat sebesar $0,35 \%$. Flavonoid, tanin dan asam galat merupakan senyawa yang tersebar luas di alam. Senyawa flavonoid dan tanin merupakan senyawa yang dikenal sebagai senyawa antioksidan dan antibakteri. Thoa, Nam, dan Nhat (2015), menemukan bahwa kandungan flavonoid pada putri malu dengan menggunakan pelarut air adalah sebesar $0,08 \%$ sedangkan dengan pelarut etanol kandungan flavonoidnya sebesar $2,43 \%$. Asam galat merupakan senyawa fenolik yang dikenal sebagai senyawa antioksidan. Menurut Lu, Nie, Belton, Tang, dan Zhao(2006), asam galat (GA) adalah senyawa fenolik antioksidan alami yang diekstrak dari tanaman, yang secara luas digunakan dalam makanan, obat-obatan, dan kosmetik.

\section{Melanosis}

Hasil pengukuran melanosis dapat dilihat pada Gambar 1. Nilai uji melanosis udang pada awal penyimpanan pada setiap perlakuan adalah 0 . Hal ini berarti bahwa melanosis belum muncul pada udang. Melanosis kemudian muncul dan tersebar selama penyimpanan. Udang kontrol mulai ditolak panelis pada hari ke-4 karena sudah mencapai nilai 4,4 dan terus mengalami penurunan hingga akhir penyimpanan dingin pada hari ke-10 dengan nilai melanosis 10 yang artinya mudah untuk dilihat di hampir semua bagian udang (noticeable on most shrimps) dan tampak heavy. Berbeda dengan kontrol, penambahan ekstrak putri malu $3 \%$ dan $5 \%$ mulai ditolak panelis pada penyimpanan dingin hari ke-8 dengan nilai 4,8 dan 4,3. Nilai melanosis konsentrasi $3 \%$ dan $5 \%$ pada akhir penyimpanan bernilai 6,13 dan 5,53 yang berarti tampak moderate dan mudah untuk dilihat di hampir semua bagian udang (noticeable on most shrimps). Perbedaan tampak heavy dan tampak moderate adalah banyaknya permukaan udang yang telah berubah warna. Tampak heavy memiliki permukaan udang lebih banyak apabila dibandingkan dengan tampak moderate. Konsentrasi $7 \%$ mulai ditolak pada hari ke-10 dengan nilai melanosis 4,8. Hal ini menunjukkan penambahan ekstrak putri malu 3\%, $5 \%$ dan $7 \%$ selama penyimpanan memberi pengaruh terhadap karakteristik melanosis pada udang serta memperlambat penurunan nilai melanosis selama penyimpanan. Menurut Otwell dan Marshall (1986) pengujian melanosis memiliki nilai standar 4 yang berarti masih layak untuk diterima oleh konsumen. Ketika nilai melanosis yang didapat sudah melebihi nilai 4 maka udang sudah tidak dapat diterima oleh panelis.

Pengaruh ekstrak tanaman putri malu pada proses melanosis disebabkan adanya kandungan antioksidan pada tanaman putri malu seperti flavonoid dan fenol. Kandungan antioksidan dapat mereduksi kembali

Tabel 1. Hasil Rendemen Ekstrak Tanaman Putri Malu Table 1. Yield of Mimosa pudica L. Plant Extract

\begin{tabular}{lcc}
\hline & $\begin{array}{c}\text { Rata-Rata/ } \\
\text { Average }\end{array}$ & $\begin{array}{c}\text { Standar Deviasi/ } \\
\text { Standard Deviation }\end{array}$ \\
\hline Berat Simplisia/Sample weight $(\mathrm{g})$ & 400.00 & 0.00 \\
Berat Ekstrak/Extract weight $(\mathrm{g})$ & 12.60 & 0.39 \\
Rendemen/Yield $(\%)$ & 3.11 & 0.09 \\
\hline
\end{tabular}

Tabel 2. Hasil Uji Metabolit Sekunder

Table 2. Secondary Metabolite Analysis Results

\begin{tabular}{lcc}
\hline \multicolumn{1}{c}{$\begin{array}{c}\text { Analisa/ } \\
\text { Analysis }\end{array}$} & $\begin{array}{c}\text { Rata-Rata/ } \\
\text { Average }(\%)\end{array}$ & $\begin{array}{c}\text { Standar Deviasi/ } \\
\text { Standard Deviation }\end{array}$ \\
\hline Flavonoid & 0.08 & $5.10^{-4}$ \\
Tanin & 0.57 & $2.10^{-3}$ \\
Asam Galat/Gallic Acid & 0.35 & $7.10^{-4}$ \\
\hline
\end{tabular}




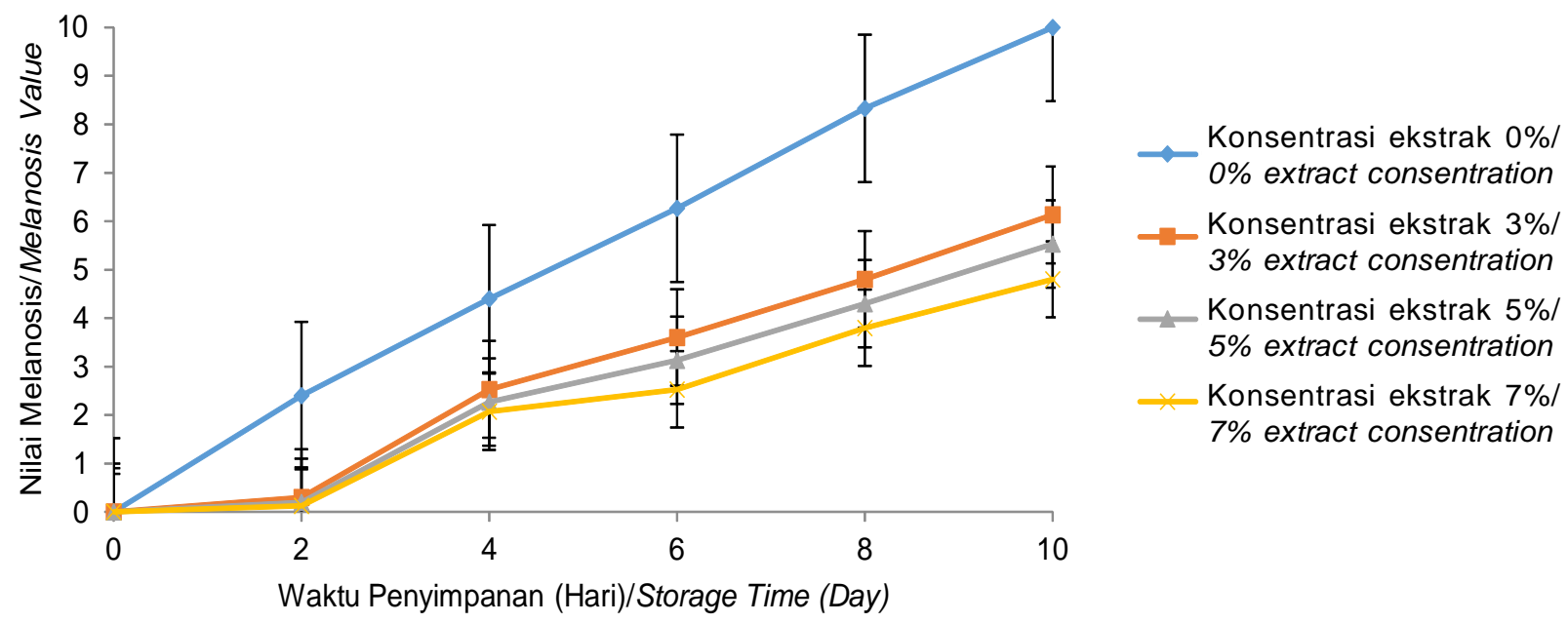

Gambar 1. Nilai melanosis udang pada berbagai perlakuan selama penyimpanan dingin Figure 1. Melanosis value of shrimp at various treatments during chilled storage

kuinon berwana hasil oksidasi (o-kuinon) yang telah terbentuk pada udang sehingga kembali ke bentuk fenolat (o-difenol) yang tidak berwarna. Menurut Goncalves, de Oliveira, dan Abrantes(2016), salah satu metode untuk menghambat melanosis adalah dengan menambah zat pereduksi seperti sulfit, asam askorbat, dan senyawa yang digunakan untuk mentransfer senyawa hidrogen (antioksidan). Senyawa fenol yang berasal dari tanaman memiliki potensi sebagai antioksidan dan antibakteri. Komponen ini umumnya berupa tokoferol, flavonoid, turunan asam sinamik, dan kumarin yang hadir secara alami pada tanaman dan memiliki efek antioksidan yang memberikan aktivitas inhibitor terhadap PPO (polifenol oksidase).

\section{Thiobarbituricacid (TBA)}

Perubahan nilai TBA ditunjukkan pada Gambar 2. Nilai TBA udang pada hari ke-0 pada kontrol dan perlakuan perendaman ekstrak putri malu $3 \%, 5 \%$, dan $7 \%$ rata-rata berturut-turut sebesar 0,$029 ; 0,014$; 0,011 dan 0,009 mg malonaldehid/kg. Nilai TBA udang kontrol, untuk perendaman ekstrak putri malu $3 \%$, $5 \%$ dan $7 \%$ tergolong baik dikarenakan kondisi udang yang digunakan untuk penelitian tergolong masih segar. Selama penyimpanan nilai TBA masing-masing perlakuan mengalami peningkatan.Peningkatan yang cukup signifikan ditunjukkan pada udang kontrol. Hasil uji TBA udang kontrol pada akhir penyimpanan bernilai $0,11 \mathrm{mg}$ malonaldehida $/ \mathrm{kg}$, untuk udang dengan

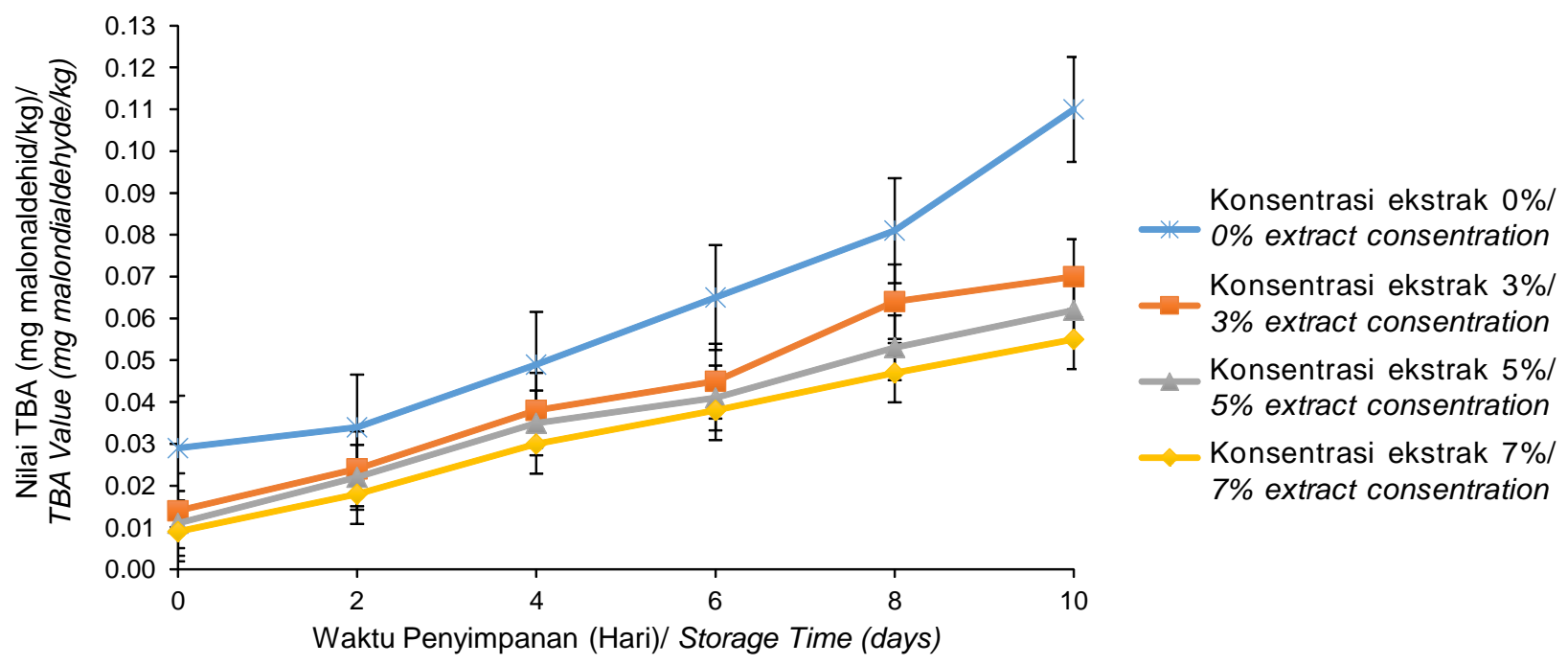

Gambar 2. Nilai thiobarbituricacid (TBA) udang pada berbagai perlakuan selama penyimpanan dingin Figure 2. Thiobarbituricacid (TBA) result of shrimp at various treatments during chilled storage 
perlakuan ekstrak tanaman putri malu $3 \%$ adalah 0,07 $\mathrm{mg}$ malonaldehida/kg, sementara konsentrasi $5 \%$ dan $7 \%$ masing-masing 0,062 dan 0,055 mg malonaldehida $/ \mathrm{kg}$. Pada semua perlakuan, nilai TBA yang didapat masih berada di bawah batas penerimaan konsumen yakni 1-2mg malonaldehida/kg (Lakshmanan, 2000).

Selama penyimpanan terdapat kenaikan nilai TBA pada udang, hal ini dikarenakan terjadinya peningkatan oksidasi dari asam lemak tak jenuh. Nilai TBA terendah didapat dari konsentrasi $7 \%$ dikarenakan perlakuan perendaman ekstrak antioksidan dapat menginhibisi oksidasi lipid pada ikan. Menurut Fan, Chi, dan Zhang (2008), peningkatan nilai TBA selama penyimpanan dapat dikaitkan dengan adanya peningkatan oksidasi asam lemak tak jenuh. Sementara Nirmal dan Benjakul (2009), mengatakan untuk nilai TBARS sampel kontrol memiliki kenaikan secara kontinyu selama hari ke-2 sampai hari ke-8, sedangkan perlakuan asam ferulik sebanyak $2 \%$ memiliki stabilitas terhadap oksidasi lipid dari pada sampel lainnya, sehingga oksidasi lipid pada udang dapat secara efektif dihambat.

\section{TVBN}

Perubahan nilai TVBN udang ditunjukkan pada Gambar 3. Nilai TVBN mengalami peningkatan selama penyimpanan pada masing-masing perlakuan. TVB udang tanpa perlakuan (kontrol) mengalami peningkatan lebih cepat dibandingkan TVB udang dengan perendaman dalam ekstrak tanaman putri malu $3 \%, 5 \%$ dan $7 \%$. Nilai TVBN udang kontrol hingga akhir penyimpanan sebesar $58,44 \mathrm{mgN} / 100 \mathrm{~g}$ sedangkan udang dengan perendaman dalam ekstrak tanaman putri malu $3 \%, 5 \%$ dan $7 \%$ berturut-turut bernilai $49,88 \mathrm{mgN} / 100 \mathrm{~g}, 46,65 \mathrm{mgN} / 100 \mathrm{~g}$, dan 44,65 $\mathrm{mgN} / 100 \mathrm{~g}$. Nilai TVBN pada perlakuan kontrol mulai melewati ambang batas penerimaan (30 mgN/100g) pada hari ke-4 yakni sebesar $31,94 \mathrm{mgN} / 100 \mathrm{~g}$ sementara pada konsentrasi $3 \%$ mulai ditolak pada hari ke-6 yakni sebesar $31,58 \mathrm{mgN} / \mathrm{kg}$. Pada konsentrasi $5 \%$, nilai TVB pada hari ke- 6 berada pada ambang batas penerimaan yakni sebesar $30,49 \mathrm{mgN} /$ $\mathrm{kg}$ dan baru berada d iatas batas penerimaan pada hari ke-8 yakni sebesar 35,18 mgN/kg.Perlakuan dengan konsentrasi $7 \%$ mulai ditolak pada hari ke-8 dengan nilai TVBN sebesar $32,4 \mathrm{mgN} / \mathrm{kg}$. Hal tersebut menunjukkan bahwa penambahan ekstrak tanaman putri malu memperlambat peningkatan nilai TVBN pada udang.

Perlakuan perendaman dalam ekstrak tanaman putri malu dengan konsentrasi 3\%,5\%,7\% menunjukkan nilai TVBN yang lebih kecil dibandingkan dengan kontrol $(0 \%)$ pada penyimpanan hari ke-2, 4, 6, 8 dan 10. Hal ini disebabkan kandungan flavonoid dan tanin pada ekstrak tanaman putri malu yang mampu menghambat pertumbuhan bakteri pada udang. Menurut Genisa (2000), terhambatnya pertumbuhan bakteri dapat menyebabkan produksi enzim menurun. Aktifitas enzim yang menurun dapat memperlambat proses pemecahan protein yang akan meningkatkan nitrogen yang mudah menguap menjadi senyawa-senyawa yang lebih sederhana penyusun TVBN.

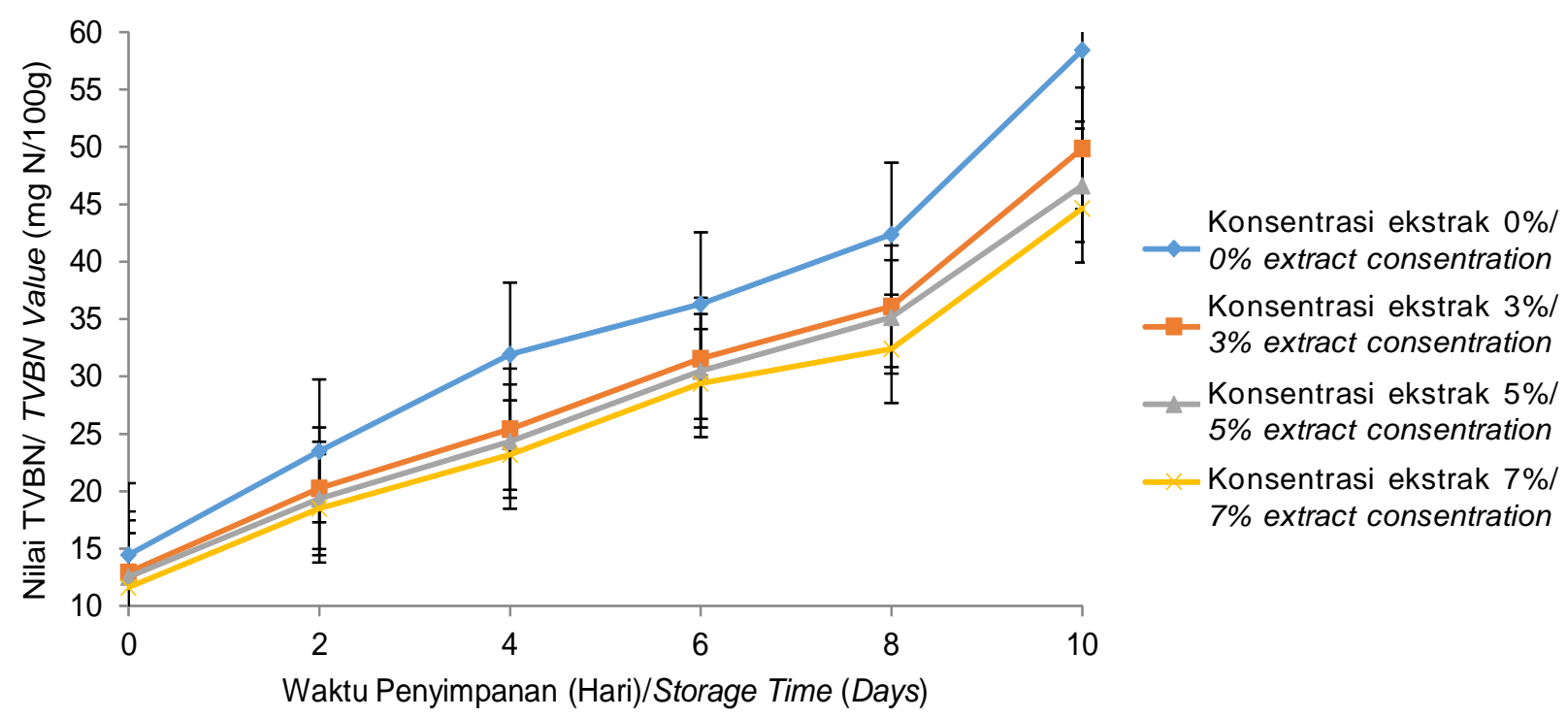

Gambar 3.Nilai TVBN udang pada berbagai perlakuan selama penyimpanan dingin

Figure 3. TVBN value of shrimp at various treatments during chilled storage 


\section{pH}

Perubahan nilai pH ditunjukkan pada Gambar 4. Derajat keasamaan $(\mathrm{pH})$ udang pada hari ke-0 pada kontrol dan perlakuan perendaman ekstrak tanaman putri malu $3 \%, 5 \%$, dan $7 \%$ memiliki nilai rata-rata sebesar 7,02; 7,02, 6,91 dan 6,87. pH udang kontrol dan udang dengan perlakuan perendaman ekstrak tanaman putri malu 3\%, 5\% dan 7\% tergolong netral dikarenakan kondisi udang yang digunakan untuk penelitian tergolong masih segar. Selama penyimpanan nilai $\mathrm{pH}$ masing-masing perlakuan mengalami peningkatan. Peningkatan yang cukup signifikan ditunjukkan pada udang kontrol dibandingkan dengan perlakuan $3 \%, 5 \%$, dan $7 \%$. Hasil uji pH udang kontrol pada akhir penyimpanan bernilai 8,34 sementara untuk udang dengan ekstrak tanaman putri malu 3\%, 5\% dan $7 \%$ secara berturutturut adalah 8,$08 ; 7,89$ dan 7,82 . Nilai pH udang tanpa perlakuan dan dengan perlakuan ekstrak tanaman putri malu $3 \%, 5 \%$ dan $7 \%$ menurun pada hari ke- 2 yaitu sebesar 6,$98 ; 6,87 ; 6,88 ;$ dan 6,75 . Hal ini disebabkan pada hari ke 2 , udang melalui fase rigor sehingga mengalami penurunan nilai $\mathrm{pH}$. Hal ini diperkuat oleh Liviawaty dan Afrianto (2014) yang menyatakan bahwa umumnya saat ikan mati $\mathrm{pH}$ ikan mendekati netral yaitu sekitar 6,8 hingga netral, selanjutnya ada pemecahan glikogen yang menghasilkan asam laktat akan meningkatkan keasaman daging yang mengakibatkan $\mathrm{pH}$ daging akan menjadi menurun.Selanjutnya, dari hari ke-4 hingga akhir penyimpanan nilai $\mathrm{pH}$ udang mengalami peningkatan. Peningkatan $\mathrm{pH}$ udang kontrol lebih tinggi dibandingkan udang dengan perlakuan esktrak tanaman putri malu. Hal tersebut menunjukkan bahwa ekstrak daun putri malu memperlambat peningkatan $\mathrm{pH}$ pada udang selama penyimpanan.

Perubahan nilai $\mathrm{pH}$ selama penyimpanan berbanding lurus dengan hasil pengujian TVBN. Kenaikan nilai $\mathrm{pH}$ selama penyimpanan dapat juga disebabkan adanya denaturasi protein menjadi senyawa-senyawa basa volatil sehingga berpengaruh pada meningkatnya nilai TVBN. Perubahan nilai $\mathrm{pH}$ selama penyimpanan mengalami peningkatan sebanding dengan naiknya nilai TVBN pada udang. Selain itu, peningkatan $\mathrm{pH}$ juga disebabkan kerusakan atau degradasi protein menjadi senyawa-senyawa yang lebih sederhana yang nantinya menghasilkan basa-basa nitrogen. Salim (2014), menambahkan nilai $\mathrm{pH}$ yang semakin meningkat adalah akibat dari meningkatnya senyawa basa yang terlepas dari bahan pada saat berlangsungnya proses pembusukan.

\section{Sensori}

Gambar 5 menunjukkan terjadinya penurunan nilai uji sensorimasing-masing perlakuan selama penyimpanan. Penurunan nilai sensori secara signifikan terjadi pada sampel udang kontrol. Nilai sensori udang kontrol pada awal penyimpanan sebesar 8,59 yang berarti udang masih segar dan layak menjadi bahan baku. Udang kemudian mengalami penurunan hingga akhir penyimpanan menjadi 3,15 yang berarti udang sudah tidak segar dan tidak layak menjadi bahan baku. Nilai masing-masing udang yang diberi perlakuan pada awal penyimpanan masih berada

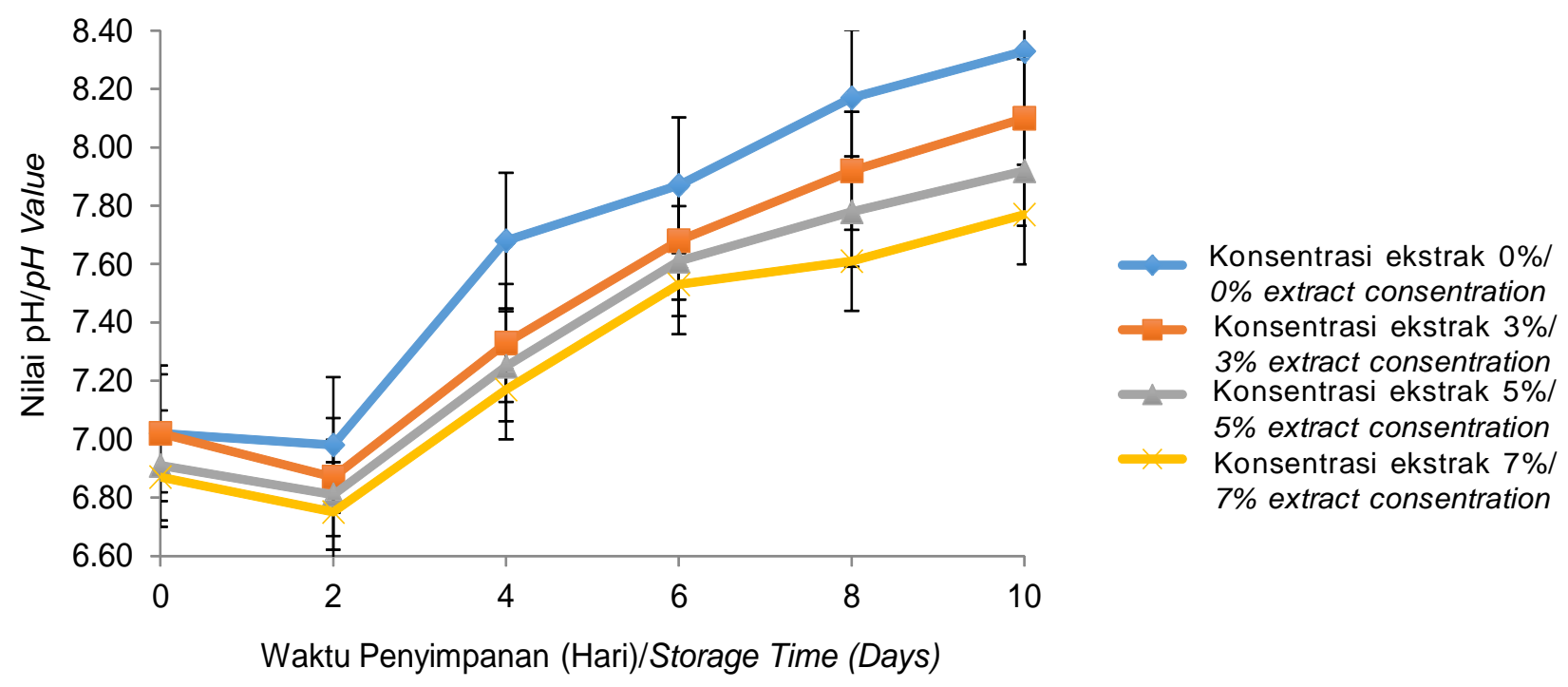

Gambar 4. Nilai pH udang pada berbagai perlakuan selama penyimpanan dingin

Figure 4. $\mathrm{pH}$ value of shrimp at various treatments during chilled storage 


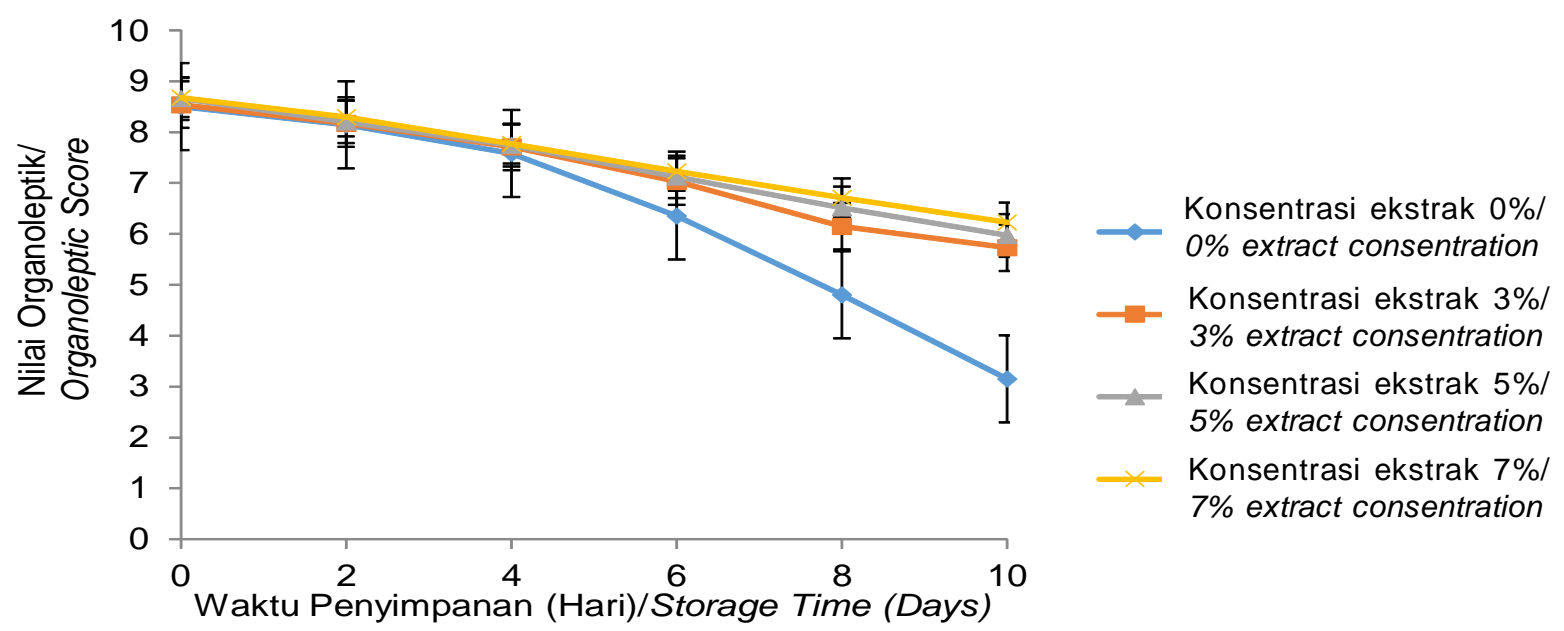

Gambar 5. Nilai sensori udang pada berbagai perlakuan selama penyimpanan dingin Figure 5. Sensory score of shrimp at various treatments during chilled storage

di atas batas penerimaan yaitu 7,00 yang berarti udang tersebut layak untuk dikonsumsi. Kemunduran mutu udang kontrol terjadi pada hari ke- 6 dengan nilai sensori 6,50, di mana udang sudah dikategorikan tidak segar dan tidak layak konsumsi sedangkan untuk udang perlakuan mulai terjadi kemunduran mutu pada hari ke-8 dengan nilai sensori 6,4 untuk 3\%, 6,76 untuk $5 \%$ dan 6,8 untuk $7 \%$. Hal tersebut menunjukkan bahwa penambahan ekstrak tanaman putri malu saat perendaman berpengaruh pada daya simpan dan mutu udang. Hal ini diperkuat oleh Taher (2010) yang menyatakan bahwa semakin lama penyimpanan maka nilai rata-rata sensori semakin menurun.

Berdasarkan pengujian sensori pada udang dengan perlakuan perendaman dan tanpa perendaman ekstrak tanaman putri malu selama penyimpanan dingin yang berbeda diperoleh hasil beda nyata pada setiap perlakuan.

Penurunan nilai sensori udang masing-masing perlakuan selama penyimpanan berbanding terbalik dengan nilai TBA, TVB, melanosis assessment dan $\mathrm{pH}$. Menurunnya nilai sensori menandakan bahwa kesegaran udang semakin menurun. Hal ini dapat didukung oleh indikator nilai melanosis, TBA dan TVBN yang semakin naik dikarenakan ketiganya merupakan tanda bahwa udang mengalami kemunduran mutu.

Penurunan secara signifikan pada nilai kenampakan sensori ditunjukkan pada udang kontrol sedangkan penurunan tidak terlalu signifikan pada sampel perlakuan. Hal ini dikarenakan penambahan ekstrak tanaman putri malu mampu menghambat penurunan mutu udang.

Karakteristik bau udang pada awal penyimpanan adalah bau spesifik jenis namun pada akhir penyimpanan udang kontrol berbau basa dibandingkan dengan udang perlakuan yang memiliki bau kurang spesifik jenis dan ada bau tanaman dengan perlakuan konsentrasi yang makin besar. Penambahan ekstrak putri malu 3\%, 5\% dan $7 \%$ selama penyimpanan memberi pengaruh terhadap karakteristik bau udang serta memperlambat penurunan nilai bau selama penyimpanan. Menurut Hermiati, Rusli, Manalu, dan Sinaga (2013), pengawet yang saat ini banyak digunakan diambil dari bahan rempah-rempah yang mengandung senyawa yang amat berbau dan berasa sehingga mempengaruhi aroma dan rasa.

Tekstur pada udang kontrol mengalami penurunan hingga penyimpanan hari ke-10, sedangkan udang dengan penambahan ekstrak tanaman putri malu $3 \%$, $5 \%$ dan $7 \%$ nilai teksturnya mengalami penurunan yang stabil. Karakteristik tekstur udang kontrol pada penyimpanan 10 hari tidak elastis, lunak dan tidak kompak, berbeda dengan tekstur udang dengan perlakuan ekstrak tanaman putri malu 3\%, 5\% dan $7 \%$ pada penyimpanan 10 hari yang memiliki karakteristik kurang elastis, kompak dan padat. $\mathrm{Hal}$ tersebut menunjukkan adanya penghambatan kemunduran mutu sensori pada udang oleh ekstrak tanaman putri malu. Penambahan ekstrak tanaman putri malu mampu mempertahankan mutu tekstur udang dibandingkan dengan udang tanpa perlakuan. Hal ini diperkuat oleh Purnomo, Kobajashi, Issamu, dan Yuwono (2012), yang menginformasikan bahwa perubahan tekstur juga disebabkan karena lapisan jaringan ke arah samping terikat kembali tapi diameter serabut otot terisi cairan yang terdifusi lewat sarkoplasma yang mengakibatkan daging menjadi lembek. Pakpahan, Khotimah, dan Turnip (2015) 
Penerapan Ekstrak Putri Malu (Mimosa pudica L..) sebagai Penghambat Melanosis.....(Nabila Tsarwatul Jannah et al.)

menambahkan bahwa tekstur sangat tergantung pada kondisi pH dan tingkat denaturasi protein.

\section{KESIMPULAN}

Kesimpulan yang didapat dari penelitian tentang pengaruh ekstrak tanaman putri malu sebagai penghambat melanosis pada udang selama penyimpanan dingin adalah sebagai berikut :

1. Ekstrak tanaman putri malu dengan berbagai konsentrasi memberikan pengaruh nyata dalam mempertahankan mutu udang dari terjadinya reaksi melanosis selama penyimpanan hingga hari ke-6.

2. Konsentrasi $7 \%$ ekstrak tanaman putri malu merupakan konsentrasi yang dapat memberikan pengaruh secara optimal dan mampu mempertahankan mutu udang hingga hari ke- 6 jika dilihat dari nilai uji melanosis, TBA dan TVBN yang terendah serta didukung dengan nilai organoleptik yang lebih tinggi dan $\mathrm{pH}$ lebih rendah. Namun, kosentrasi 7\% merupakan konsentrasi maksimum dikarenakan pada perlakuan $7 \%$ ditemukan bau daun yang samar.

\section{DAFTAR PUSTAKA}

Anggraini., Hamidah, A., \& Moehammadi, N. (2013). Uji efektivitas ekstrak daun jeruk purut (Citrus hystrix D.C) dan daun jeruk kalamondin (Citrus mitis Blanco) sebagai biolarvasida terhadap kematian larva instar III nyamuk Aedes aegypti L. Jurnal IImiah Biologi, 1(1),1-10.

Azmi, L., Singh, M. K., \& Akhtar, A. K. (2011). Pharmacological and biological overview on Mimosa pudica Linn. Int. J. of Pharm. \& Life Sci., 2(11), 12261234.

Badan Standardisasi Nasional (BSN).(2004). SNI 066989.11: Air dan air limbah - Bagian 11: Cara uji derajat keasaman $(\mathrm{pH})$ dengan menggunakan alat $\mathrm{pH}$ meter. Badan Standarisasi Nasional (BSN). Jakarta.

Badan Standardisasi Nasional (BSN). (2006). SNI 01 2346: Petunjuk Pengujian Organoleptik dan atau Sensori. Badan Standarisasi Nasional (BSN). Jakarta.

Badan Standardisasi Nasional (BSN). (2009). SNI 2354.8: Penentuan kadar Total Volatil Base Nitrogen (TVB-N) dan Trimetil Amin Nitrogen (TMA-N) pada produk perikanan. Badan Standarisasi Nasional (BSN). Jakarta.

Erkan, N., Ozden, O., Alakavuk, U. D., Tosun, S. Y., Varlik, C., \& Baygar, T. (2007). Istanbul'da satýlan karideslerin sodyum metabisülfit düzeyinin tespiti (determination of sodium metabisulphite levels of shrimps sold in Istanbul). Journal of FisheriesSciences.com,1(1), 26-33.
Fadlian, B. H., \& P. H. Abram. (2016). Uji efektivitas ekstrak tanaman putri malu (Mimosa Pudica Linn) sebagai bahan pengawet alami tomat. Jurnal Akademika Kimia, 5(4), 153-158.

Fan, W., Chi, Y., \& Zhang, S. (2008). The use of a tea polyphenol dip to extend the shelf life of silver carp (Hypophthalmicthys molitrix) during storage in ice. Food Chemistry, 108(2008), 148-153.

Genisa, J. (2000). Produksi Histamin pada ikan cakalang (Katsuwonus pelamis L) selama lepas tangkap. Disertasi. Pascasarjana Ilmu Teknologi Pertanian Universitas Hasanuddin, Makassar, pp. 59.

Gomez-Guillen, M. C., Martinez-Alvarez, O., Llamas, A., \& Montero, P. (2005). Melanosis inhibition and SO2 residual levels in shrimp (Parapenaeus longirostris) after different sulfite-based treatments. Journal of the Science of Food and Agriculture, 85,1143-1148.

Goncalves, A. A., de Oliveira, A. R. M., \& Abrantes, M. R. (2016). Acerola fruit as a possible antimelanotic agent in white shrimp (Litopenaeus vannamei).Journal of Food Processing( Volume 2015, 65, 791-799.

Harboune, J. B. (1987). Metode fitokimia penuntun cara modern menganalisa tumbuhan. Diterjemahkan oleh Kosasi Padmawinata dan Imam Sudiro. Edisi I. ITB. Bandung

Hermiati., Rusli, N. Y., Manalu., \& Sinaga, M. S. (2013). Ekstrak daun sirih hijau dan merah sebagai antioksidan pada minyak kelapa. Jurnal Teknik Kimia USU, 2(1), 37-43.

Lakshmanan, P. T. (2000). Fish spoilage and quality assessment.In T. S. G. lyer, M. K. Kandoran, Mary Thomas, \& P. T. Mathew (Eds.), Quality assurance in seafood processing, (pp. 26-40). Cochin: Society of Fisheries Technologists, India.

Lakshmibai, R., Amirtham, D., \& Radhika, S. (2016). Preliminary phytochemical analysis and antioxidant activities of prosopis juliflora and Mimosa Pudica $L$. International Journal Of Scientific Engineering And Technology Research, 4(30),5766-5770.

Liviawaty, E., \& Afrianto, E. (2014). Penentuan waktu rigor mortis ikan nila merah (Oreochromis niloticus) berdasarkan pola perubahan derajat keasaman. Jurnal Akuatika, V(1), 40-44.

Lu, Z., Nie, G., Belton, P. S., Tang, H., \& Zhao, B. (2006). Structure-activity relationship analysis of antioxidant ability and neuroprotective effect of gallic acid derivatives. Neurochemistry International, 48,263274.

Montero, P., Martínez-Álvarez, O., \& Gómez-Guillén, M. C. (2004). Effectiveness of onboard application of 4hexylresorcinol in inhibiting melanosis in shrimp (Parapenaeus longirostris). Journal Of Food Science, 69(8), 643-647.

Nirmal, N. P. \& Benjakul, S. (2009). Effect of ferulic acid on inhibition of polyphenoloxidase and quality changes of Pacific white shrimp (Litopenaeus vannamei) during iced storage. Food Chemistry, 116, 323-331.

Otwell, W. S., \& Marshall, M. R. (1986). Studies on the use of sulfites to control shrimp melanosis (blackspot): screen alternatives to sulfiting agents to 
control shrimp melanosis. Florida Seagrant Technical Paper, 46, 1-10.

Pakpahan, R. A., Khotimah, S. \& Turnip, M. (2015). Efektivitas ekstrak etanol daun sirih (Piper betle L.) dan buah mengkudu (Morinda citrifolia L.) sebagai alternatif pengawet tahu. Jurnal Protobiant, 4(1), 115119.

Pal, P., Datta, S., Basnett, H., Shrestha, B., Mohanty, J. P. (2015). Phytochemical analysis of the whole plant of Mimosa pudica (Linn.). UJPSR., 1(1), 1-9.

Patro, G., Bhattasamisra, S. K., Mohanty, B.K., \& Sahoo, H. B. (2016). In Vitro antioxidant evaluation and estimation of total phenolic, flavonoidal content of Mimosa pudica L. Pharmacognosy research, 8(1), 2228.

Purnomo, H., Kobajashi, T., Issamu., \& Yuwono, S. S. (2012). Karakteristik fisik, kimia, dan organoleptik ikan cakalang (Katsuwonus pelamis) asap di Kendari. Jurnal Teknologi Pertanian, 13(2), 105-110.

Pendit, P. A. C. D., Zubaidah, E., \& Sriherfyna, F. H. (2016). Karakteristik fisik kimia dan aktivitas antibakteri ekstrak aaun belimbing wuluh (Averrhoa bilimbi L). Jurnal Pangan dan Agroindustri, 4(1), 400-409.

Racadio, S. P. (2016). The medicinal prospects of makahiya (Mimosa pudica Linn) Plant. Advances in Life Sciences 2016, 6(1), 7-12.
Salim, M.R. (2014). Aplikasi model Arrhenius untuk pendugaan masa simpan sosis ayam pada penyimpanan dengan suhu yang berbeda bedasarkan nilaiTVB dan $\mathrm{pH}$. Tesis. Program Studi Magister Teknologi Industri Pangan Fakultas PascasarjanaUniversitas Pasundan, Bandung. 119.

Suryanto, E. (2007). Aktivitas antioksidan ekstrak flavanoid dari buah andaliman (Zanthoxylum acathopodium DC) pada Ikan Mas (Cyperinus carpio L). Jurnal Sains, Unsrat, Manado

Tarladgis, B. G., Watts, B. M., \& Younathan, M. T. (1960). A distillation method for the quantitative determination of malonaldehyde in rancid foods. Journal of The American Oil Chemists Society, 37(1), 44-48.

Taher, N. (2010). Penilaian mutu organoleptik ikan mujair (Tilapia mossambica) segar dengan ukuran yang berbeda selama penyimpanan dingin. Jurnal Perikanan dan Kelautan, VI(1),8-12.

Thoa, N. T. L., Nam, P. C., \& Nhat, D. M. (2016). Antibacterial activities of the extracts of Mimosa pudica L. an in-vitro study. International Journal on Advanced Science Engineering Information Technology, 5(5), 358-361.

Zhang, J., Yuan, K., Zhou, W. L., Zhou, J., \&Yang, P. (2011). Studies on the active components and antioxidant activities of the extract of Mimosa pudica Linn. from Southern China. Pharmacognosy Magazine, 7(25), 35-39. 